\title{
Pengaruh Model Pembelajaran Project Based Learning Terhadap Peningkatan Kemampuan Self-Regulated Learning Mahasiswa Universitas Advent Indonesia
}

\author{
Nora Susilowaty \\ Universitas Advent Indonesia, \\ Program Studi Pendidikan Matematika \\ nora.nainggolan@unai.edu
}

\begin{abstract}
Abstrak: Penelitian ini bertujuan untuk mengetahui efektifitas model pembelajaran project based learning terhadap peningkatan kemampuan self regulated learning mahasiswa UNAI. Penelitian ini merupakan pre eksperimental dengan menggunakan one group pretest-postest design sebagai desain penelitian. Sampel penelitian ini adalah satu kelas mahasiswa fakultas ekonomi yang mengambil mata kuliah statistik bisnis I di Universitas Advent Indonesia dengan menggunakan teknik purposive sampling. Pengambilan data dilakukan dengan menggunakan tes angket skala self regulated learning mahasiswa yang sudah diuji validitasnya dan melalui wawancara. Skala likert ini diubah menjadi skor baku z yang selanjutnya dianalisis dengan menggunakan uji statistik non parametrik Wilcoxon Signed Rank Test. Hasil penelitian menyatakan bahwa kemampuan self-regulated learning mahasiswa sesudah diterapkan Project Based Learning lebih baik dibandingkan sebelum diterapkan Project Based Learning. Berdasarkan hasil analisis data penelitian, disarankan bahwa model pembelajaran project based learning dapat dijadikan salah satu pilihan pembelajaran di kelas untuk mengembangkan kemampuan self regulated learning mahasiswa ataupun kemampuan kognitif, afektif, juga kemampuan lainnya. Selain itu dapat juga diterapkan pada mata kuliah lainnya. Hasil wawancara menunjukkan mahasiswa yang diwawancarai menyatakan bahwa mereka menjadi lebih mandiri dan lebih siap dalam belajar statistik di kelas.
\end{abstract}

Kata kunci: $\quad$ Project based learning, kemampuan self regulated learning

\section{Pendahuluan}

Pendidikan adalah faktor yang sangat penting bagi kemajuan suatu bangsa. Perkembangan pendidikan yang cukup pesat saat ini perlu ditanggapi dengan cermat oleh para pendidik. Menanggapi perkembangan tersebut, pemerintah mewajibkan Perguruan Tinggi untuk 
menyiapkan mahasiswanya tanggap menghadapi persaingan global. Hal ini tersirat dalam Undang-undang Nomor 12 tahun 2012 yang menyatakan bahwa untuk meningkatkan daya saing bangsa dalam menghadapi globalisasi di segala bidang, diperlukan pendidikan tinggi yang mampu mengembangkan ilmu pengetahuan dan teknologi.

Salah satu tujuan Pendidikan Tinggi dalam Undang-undang Nomor 12 tahun 2012 adalah dihasilkannya Ilmu Pengetahuan dan Teknologi melalui Penelitian yang memperhatikan dan menerapkan nilai Humaniora agar bermanfaat bagi kemajuan bangsa, serta kemajuan peradaban dan kesejahteraan umat manusia. Untuk mencapai tujuan pendidikan diatas maka perlu diberikan pembelajaran yang mengajak mahasiswa untuk menghasilkan karya penelitian yang bermanfaat dalam dunia pendidikan atau dalam ilmu pengetahuan dan teknologi serta untuk kemajuan bangsa.

Hal ini berarti bahwa penting bagi Mahasiswa dituntut untuk menguasai keterampilan dan tanggung jawab baru serta perubahan dalam bentuk praktek.

Membiasakan mahasiswa untuk menghasilkan suatu karya penelitian bukan hal yang mudah. Diperlukan kemandirian belajar yang akan membiasakan mahasiswa mampu memonitor, meregulasi, mengontrol aspek kognisi, motivasi dan perilaku diri sendiri dalam belajar yang disebut sebagai self-regulated learning. Pengertian self regulated learning menurut seorang ahli psikologi Zimmerman (1990) merupakan kemampuan diri untuk memonitor pemahamannya, untuk memutuskan kapan siap diuji, untuk memilih strategi pemrosesan informasi yang baik. Zimmerman (1990) mengemukakan tiga unsur dalam self-regulated learning yaitu (1) metacognitive, meliputi proses pemahaman akan kesadaran dan kewaspadaan diri serta pengetahuan dalam menentukan pendekatan pembelajaran sebagai salah satu cara didalam proses berpikir; (2) motivational, individu yang memiliki motivasi adalah individu yang memiliki fokus terhadap pentingnya usaha luar biasa dan ketekunan dalam belajar; (3) behaviorally active participants, perilaku partisipasi aktif merupakan respon yang dipengaruhi oleh beberapa proses seperti perilaku yang baik yang ditampilkan pada suatu lingkungan. 
Pintrich \& De Groot (1990) mengatakan bahwa "peserta didik dapat memahami bagaimana mereka harus belajar, siswa mengetahui tentang bagaimana mereka memilih strategi dalam meregulasi dirinya dalam belajar (Self-Regulated Learning)" yang akan merefleksikan tujuan jangka panjang bagi pendidikan mereka, dan hal ini berkaitan dengan bagaimana siswa mempunyai keterampilan dalam belajar.

Menanggapi hal tersebut perlu ditumbuh-kembangkan self-regulated learning (kemandirian belajar) mahasiswa. Kemampuan ini menjadikan mahasiswa berpartisi aktif terkait kognitif, motivasi dan perilaku dalam proses pembelajaran (Zimmerman, 1990). Self regulated learning memiliki peranan penting dalam akademik yang dicapai siswa, salah satunya dipengaruhi oleh kepercayaan diri siswa terhadap kemampuannya (Pintrich \& De Groot, 1990). Siswa yang memiliki motivasi tinggi dalam belajar, mampu mengatur dan menempatkan dirinya untuk mencapai tujuan belajarnya, dan siswa yang memiliki self-regulated learning tinggi akan mampu menyelesaikan tugas belajarnya secara mandiri.

Beberapa hasil penelitian menunjukkan bahwa self-regulated learning mempunyai pengaruh positif terhadap pembelajaran dan pencapaian hasil belajar. Izzati (2012) mengungkapkan bahwa self-regulated learning berkorelasi kuat dengan kesuksesan seorang siswa. Hal serupa dikatakan Sumarmo (2012) yang menemukan bahwa individu yang memiliki self-regulated learning yang tinggi cenderung belajar lebih baik, mampu memantau, mengevaluasi, dan mengatur belajarnya secara efektif, menghemat waktu dalam menyelesaikan tugasnya, mengatur belajar dan waktu secara efisien, dan memperoleh skor yang tinggi dalam sains. Nurfiani (2015) menegaskan hasil penelitiannya menunjukan bahwa tingkat kemampuan self-regulated learning pada siswa kelas X di SMK Negeri 1 Kalasan secara keseluruhan berada pada kategori sedang, yaitu dengan perolehan kemampuan self-regulated learning dalam kategori sedang yakni 28 siswa (45\%). Hasil analisis pada setiap aspeknya yakni, pada 1) aspek perencanaan berada 
pada kategori sedang dengan jumlah 32 siswa (52\%) yang meliputi menentukan strategi belajar yang akan digunakan, merasa memiliki kewajiban untuk menyelesaikan tugas, dan mengatur diri untuk persiapan belajar, 2) pada aspek pelaksanaan berada pada kategori sedang dengan jumlah 28 siswa (45\%) meliputi menerapkan strategi kognitif dan metakognitif, memonitor dan mengontrol emosi dan motivasi belajar, dan melakukan kegiatan, serta 3) aspek evaluasi berada pada kategori sedang, dengan jumlah siswa dalam kategori sedang 28 siswa (45\%) meliputi memilih strategi untuk mengatasi kegagalan, merasa mampu mengevaluasi hasil belajar, meninjau kembali hasil pekerjaan sendiri. Ini berarti bahwa kemampuan self-regulated learning pada siswa masih belum tinggi. Berkaitan dengan hal tersebut self-regulated learning menjadi kemampuan yang penting dan harus dimiliki oleh siswa.

Adapun indikator self-regulated learning dalam penelitian ini yaitu: inisiatif belajar, memiliki kemampuan menentukan nasib sendiri, mendiagnosis kebutuhan belajar, kreatif dan inisiatif dalam memanfaatkan sumber belajar dan memilih strategi belajar, memonitor, mengatur dan mengontrol belajar, mampu menahan diri, membuat keputusankeputusan sendiri dan mampu mengatasi masalah

Merealisasikan tercapainya kemampuan self regulated learning mahasiswa yang tinggi, maka dibutuhkan pembelajaran inovatif yang melibatkan keaktifan mahasiswa secara kolaboratif dalam pemecahan masalah, menyelesaikan tugas-tugas bermakna, mengkontruksi pengetahuan, dan menghasilkan produk nyata, sehubungan dengan materi tertentu yang dipelajari. Salah satu pembelajaran yang menciptakan situasi yang aktif, dan kolaboratif adalah Project-Based Learning (Pembelajaran Berbasis Proyek). ProjectBased Learning merupakan model pembelajaran yang berfokus pada konsep-konsep dan prinsip-pinsip utama dari suatu disiplin ilmu, melibatkan mahasiswa dalam kegiatan pemecahan masalah dan tugas-tugas bermakna lainnya, memberi peluang mahasiswa bekerja secara otonom mengkonstruksi belajar mereka sendiri, dan menghasilkan produk karya mahasiswa (Santyasa \& Sukadi, 2007). 
Secara umum, Project-Based Learning menempuh tiga tahap, yaitu: (1) perencanaan proyek meliputi, identifikasi masalah nyata, menemukan alternatif dan merumuskan strategi penyelesaian masalah, serta melakukan perencanaan. (2) pelaksanaan proyek meliputi, pembimbingan mahasiswa dalam penyelesaian tugas, melakukan pengujian produk (evaluasi), dan presentasi antar kelompok. (3) evaluasi proyek berupa penilaian proses dan produk yang meliputi, kemajuan belajar proyek, proses actual dari penyelesaian masalah, kemajuan kinerja tim dan individual, buku catatan dan catatan penelitian, kontrak belajar, penggunaan komputer dan refleksi. Sedangkan penilaian produk seperti hasil kerja dan presentasi, tugas-tugas non tulis, dan laporan proyek (Lestari \& Yudhanegara, 2015).

Adapun tujuan dari penelitian ini adalah untuk mengetahui apakah kemampuan selfregulated learning mahasiswa sesudah diterapkan Project Based Learning lebih baik dibandingkan sebelum diterapkan Project Based Learning.

\section{METODE PENELITIAN}

Penelitian yang dilakukan adalah pre-experimental dengan desain one-group pretestposttest design. Dimana objek penelitian tidak dipilih secara acak. Desain ini dapat digambarkan sebagai berikut (Lestari \& Yudhanegara, 2015 ):

\section{$\mathrm{O} \quad \mathrm{X} \quad \mathrm{O}$}

Keterangan:

$\mathrm{O}=$ Pretes dan postes

$\mathrm{X} \quad=$ Perlakuan model pembelajaran Project based learning

Penelitian ini dilakukan kepada Mahasiswa tingkat II semester ganjil fakultas ekonomi Universitas Advent Indonesia pada tahun ajaran 2019/2020 yang mengambil mata kuliah statistik I. Populasi dalam penelitian ini adalah mahasiswa fakultas ekonomi tingkat II yang mengambil mata kuliah statistik I, sedangkan sampel dalam penelitian ini adalah satu kelas dari mahasiswa fakultas ekonomi tingkat II yang mengambil mata kuliah statistik I. 
Penentuan sampel dilakukan dengan teknik purposive sampling, artinya sampel tidak dipilih secara acak karena tidak mungkin mempelajari semua keseluruhan populasi maka peneliti menggunakan sampel yang diambil dari populasi. Dari 4 kelas yang tersedia, hanya 1 kelas yang dijadikan sampel penelitian, yaitu section BAK. Pemilihan kelas didasarkan karena peneliti mengajar mata kuliah statistik I dikelas tersebut.

Instrumen penelitian berupa skala self-regulated learning, serta catatan dilapangan. Selain itu ada instrument pembelajaran yang digunakan pada saat kegiatan pembelajaran dilakukan yaitu RPP dan LKS. Data tes skala self-regulated learning yang menggunakan skala Likert ditransformasikan ke dalam skor-z. kemudian untuk melihat apakah terdapat pengaruh terhadap peningkatan kemampuan self-regulated learning mahasiswa sebelum dengan sesudah dilakukan perlakuan project based learning, maka data skor selfregulated learning akan dianalisis dengan menggunakan uji Wilcoxon Sign Rank Test.

Hipotesis statistik yang digunakan dalam penelitian ini sebagai berikut:

$\mathrm{H}_{\mathrm{o}}: R_{\text {posPBL }} \leq R_{\text {prePBL }}$

(kemampuan self-regulated learning mahasiswa sesudah diterapkan Project Based Learning tidak lebih baik dibandingkan sebelum diterapkan Project Based Learning )

$H_{1}: R_{\text {posPBL }}>R_{\text {prePBL }}$

(kemampuan self-regulated learning mahasiswa sesudah diterapkan Project Based Learning lebih baik dibandingkan sebelum diterapkan Project Based Learning )

Keterangan:

$R_{\text {prePBL }}=$ kemampuan self-regulated learning mahasiswa sebelum diterapkan Project based learning

$R_{\text {posPBL }}=$ kemampuan self-regulated learning mahasiswa sesudah diterapkan Project based learning

Uji Wilcoxon dengan pendekatan distribusi normal sebagai berikut:

$z=\frac{W_{+}-\mu_{W}}{\sigma_{W}} \quad($ Uyanto, 2009) 
Dimana :

W: Jumlah jenjang/ rangking yang kecil

$\mu_{W}=\frac{n(n+1)}{4}$

$\sigma_{W}=\sqrt{\frac{n(n+1)(2 n+1)}{24}}$

Analisis data dan uji statistik yang dilakukan menggunakan Microsoft Excel 2016 dan SPSS 23, kemudian hasilnya akan diberikan interpretasi yang sesuai dan mewakili.

\section{HASIL PENELITIAN DAN PEMBAHASAN}

Pengukuran kemampuan self-regulated learning yang dialami siswa pada kelas yang diberikan model project based learning, dilakukan dengan memberikan tes skala selfregulated learning matematik. Tes terdiri atas 25 pernyataan yang disajikan dalam bentuk skala Likert yang telah divalidasi. Tes diberikan kepada siswa pada awal pembelajaran yaitu sebelum diberi perlakuan berupa pembelajaran dengan model Project-Based Learning ( Pre PBL), kemudian diakhir pembelajaran yaitu setelah pembelajaran dengan model Project-Based Learning ( Pos PBL).

Skala Likert ini kemudian diubah menjadi skor baku z (Sumarmo, 2014). Selanjutnya skor baku dianalisis dengan menggunakan uji statistik nonparametrik Wilcoxon Signed Rank Test (Uyanto, 2009).

Data kemampuan self-regulated learning diperoleh melalui pretes dan postes. Berikut ini disajikan deskripsi hasil pretes dan postes pada tabel 1.

\section{Tabel 1}

\section{Data Hasil kemampuan self-regulated learning}

\begin{tabular}{|l|r|r|r|r|r|}
\hline & \multicolumn{1}{|c|}{ N } & \multicolumn{1}{c|}{ Minimum } & Maximum & \multicolumn{1}{l|}{ Mean } & \multicolumn{1}{c|}{ Std. Deviation } \\
\hline Pre_PBL & 36 & 54.00 & 113.00 & 81.3333 & 17.32381 \\
Pos_PBL & 36 & 79.00 & 113.00 & 92.9167 & 9.71119 \\
Valid N (listwise) & 36 & & & & \\
\hline
\end{tabular}


Berdasarkan tabel 1, diperoleh rataan pretes dan postes berbeda. Dapat dilihat bahwa Rataan postes lebih tinggi daripada rataan pretes. Artinya kemampuan self-regulated learning mahasiswa meningkat dibandingkan sebelum diberikan perlakuan.

Hasil perhitungan uji Wilcoxon Signed Rank Test dapat dilihat pada tabel 2 dan tabel 3.

Tabel 2 Data Rank Test

\begin{tabular}{|l|r|r|r|}
\hline & N & Mean Rank & Sum of Ranks \\
\hline Pos_PBL - prePBL Negative Ranks & $10^{\mathrm{a}}$ & 8.45 & 84.50 \\
& $22^{\mathrm{b}}$ & 20.16 & 443.50 \\
Positive Ranks & $4^{\mathrm{c}}$ & & \\
Ties & 36 & & \\
Total & & & \\
\hline
\end{tabular}
a. pos_PBL $<$ pre_PBL
b. pos_PBL > pre_PBL
c. pos_PBL $=$ pre_PBL

Tabel 3 Data Hasil Uji Statistik

\begin{tabular}{|l|r|}
\hline & Pos_PBL - pre_PB \\
\hline Z & $-3.360^{\mathrm{b}}$ \\
Asymp. Sig. (2-tailed) & .001 \\
\hline
\end{tabular}

a. Wilcoxon Signed Ranks Test

b. Based on negative ranks.

Tabel 2 menunjukkan bahwa jumlah rank negatif $=84,50$ dengan rata-rata rank $=8,45$ dan jumlah rank positif $=443,50$ dengan rata-rata rank $=20,16$. Tabel 3 menunjukkan hasil uji statistik Wilcoxon Signed Ranks Test, yaitu diperoleh nilai $\mathrm{Z}=-3.360$ berdasarkan pada rank negatif. Karena pengujian yang dilakukan adalah uji satu pihak (uji pihak kanan) maka nilai Sig.p-value (2-tailed) 0,001 harus dibagi dua $\frac{0,001}{2}=0,0005$. Nilai Sig.p-value (1-tailed) lebih kecil dari 0,05, artinya $H_{0}$ ditolak, akibatnya $H_{1}$ diterima. Jadi dapat disimpulkan bahwa kemampuan self-regulated learning mahasiswa sesudah diterapkan 
Project Based Learning lebih baik dibandingkan sebelum diterapkan Project Based Learning.

Dilakukan wawancara terhadap mahasiswa, hasil wawancara menunjukkan bahwa sebagian besar mahasiswa yang diwawancarai menyatakan bahwa mereka menjadi lebih mandiri, lebih siap dalam belajar statistik di kelas, memiliki inisiatif belajar yang tinggi, mampu mendiagnosis kebutuhan belajar, lebih kreatif dan inisiatif dalam memanfaatkan sumber belajar mampu memonitor, mengatur dan mengontrol belajar, mampu membuat keputusan-keputusan sendiri dan mampu mengatasi masalah yang diberikan oleh dosen dikelas.

\section{KESIMPULAN DAN SARAN}

Berdasarkan hasil analisis data dan pembahasan, diperoleh kesimpulan bahwa kemampuan self-regulated learning mahasiswa sesudah diterapkan Project Based Learning lebih baik dibandingkan sebelum diterapkan Project Based Learning. Hasil wawancara menunjukkan bahwa sebagian besar mahasiswa yang diwawancarai menyatakan bahwa mereka menjadi lebih mandiri dan lebih siap dalam belajar statistik di kelas.

Berdasarkan hasil analisis data dan pembahasan, maka peneliti memberikan beberapa saran sebagai berikut: (1) Model pembelajaran project based learning dapat dijadikan salah satu pilihan pembelajaran dikelas untuk mengembangkan kemampuan self regulated learning mahasiswa ataupun kemampuan kognitif, afektif, juga kemampuan lainnya. (2) Model pembelajaran ini juga dapat diterapkan pada mata kuliah lainnya.

\section{DAFTAR PUSTAKA}

Izzati, N. (2012). Peningkatan Kemampuan Komunikasi Matematis dan Kemandirian Belajar Siswa SMP melalui Pendekatan Pendidikan Matematika Realistik. Disertasi pada PPS UPI Bandung: Tidak diterbitkan. 
Jurnal Padegogik, Volume 03 Issue 1, February 2020, pp. 71-80

Lestari \& Yudhanegara. (2015). Penelitian Pendidikan Matematika. Penerbit: Refika Aditama

Nurfiani, H. (2015). Survei Kemampuan Self-Regulated Learning (Srl) Siswa Kelas X Smk Negeri 1 Kalasan. Skripsi: Universitas Negeri Yogyakarta.

Pintrich, P. R., \& De Groot, E. V. (1990). Motivational and self regulated learning components of classroom academic performance. Journal of educational psychology, 82(1), 33.

Santyasa, \& Sukadi. (2007). Model-model pembelajaran Inovatif. Materi Pelatihan sertifikasi Guru di Provinsi Bali, Undiksha.

Sumarmo, U. (2012). Pendidikan karakter serta Pengembangan Berfikir dan Disposisi Matematik dalam Pembelajaran Matematika. Makalah disajikan pada Seminar Nasional di NTT pada tanggal 25 Februari 2012.

Undang-Undang Nomor 12 Tahun 2012 tentang Pendidikan Tinggi: http://sumberdaya.ristekdikti.go.id/wp-content/uploads/2016/02/uu-nomor-12tahun- 2012-ttg-pendidikan-tinggi.pdf

Uyanto, S. (2009). Pedoman Analisis Data dengan SPSS. Penerbit: Graha Ilmu

Zimmerman, B. J. (1990). Self-Regulated Learning and academic achievement: An overview. Educational psychologist, 25(1), 3-17. 